Research Article

\title{
Colorimetric detection of fluoxetine using citrate-capped silver nanoparticles
}

\author{
Sana Laghari ${ }^{1} \mathbb{D} \cdot$ Muhammad Yar Khuhawar $^{1}$
}

Received: 26 July 2019 / Accepted: 4 March 2020 / Published online: 7 March 2020

(c) Springer Nature Switzerland AG 2020

\begin{abstract}
A novel colorimetric assay has been presented for the detection of fluoxetine using citrate-capped silver nanoparticles (CIT-Ag NPs) as a colorimetric sensor. The detection of fluoxetine was accomplished by observing color change of CIT-Ag NPs solution from yellow to dark brown due to aggregation induced by fluoxetine. The aggregation of CIT-Ag NPs was characterized by various techniques including UV-Vis spectrometry, scanning electron microscopy, Fourier transform infrared spectroscopy, dynamic light scattering, and zeta potential. A characteristic absorption peak of CIT-Ag NPs at $400 \mathrm{~nm}$ was red shifted and surface plasmon resonance band became broad due to addition of fluoxetine. Under optimized conditions, linear calibration curve was obtained within concentration range of $2-10 \mu \mathrm{g} / \mathrm{ml}$ with detection limit of $0.18 \mu \mathrm{g} / \mathrm{ml}$. Furthermore, the developed colorimetric assay was found to be simple, sensitive, reproducible, and selective towards a number of pharmaceutical additives. It involved sensing of fluoxetine by naked eye within few minutes without requiring any complicated instrumentation. Colorimetric platform was applied to detect fluoxetine in pharmaceutical formulation, and biological fluids including spiked human urine and blood serum samples.
\end{abstract}

Keywords Citrate-capped Ag NPs · Fluoxetine · Colorimetric sensor · UV-Vis spectrometry · FT-IR spectroscopy

\section{Introduction}

Depression is a mental disorder. It is potentially fatal leading to suicidal thoughts. About $50 \%$ of depressed patients try to kill themselves and up to $15 \%$ die from suicide. An estimated 676 million people are affected by depression [1]. It is caused due to low level of serotonin which is a neurotransmitter. Antidepressants are used to treat depression. Fluoxetine $\mathrm{HCl}$ having IUPAC name $\mathrm{N}$-methyl3-phenyl-3-[4-(trifluoromethyl) phenoxy] propan-1-amine hydrochloride, is a diphenhydramine derivative belonging to selective serotonin reuptake inhibitors. It is widely prescribed to treat various mental disorders including obsessive compulsive disorder, panic disorder, and major depressive disorder [2]. The mechanism of action of cited antidepressant is different from tricyclic antidepressants.
However, fluoxetine is safer to use than tricyclic antidepressants owing to less side effects and is of comparable efficacy [3-5]. Due to its widespread use, there is a need to develop a simple, easy, and rapid method for assessing the quality of fluoxetine in pharmaceutical preparation and biological fluids. In this regard, several methods have been proposed in past to analyze fluoxetine in pharmaceutical formulation, spiked urine and blood serum samples including capillary electrophoresis [6, 7], HPLC [8-12], voltammetry [13], spectrophotometry [14-16] and gas chromatography [17]. No doubt, most of these methods are highly sensitive but they require tedious procedures and expensive chemicals.

Recently, nanotechnology is considered as an emerging technology in many fields including biology, information and communication technology, metrology, chemistry,

Sana Laghari, lagharisana179@gmail.com | 'Institute of Advanced Research Studies in Chemical Sciences, University of Sindh, Jamshoro 76080, Pakistan. 
physics, medicine and medical technology $[18,19]$. The properties of substance vary dramatically at the nanoscale level. The metallic nanoparticles specially, gold and silver nanoparticles are employed as colorimetric probe for biosensing and chemical sensing due to their unique interparticle distance dependent and size dependent solution color and absorption spectrum [20]. Gold and silver nanoparticles exhibit one of the most remarkable features called localized surface plasmon resonance (LSPR). It refers to collective oscillation of conduction electrons of noblemetal nanoparticles when their frequency becomes equal to that of incident electromagnetic radiation [21]. The LSPR phenomenon possessed by metallic nanoparticles in turn depend upon the composition, shape, size, dielectric constant, and inter-particle distance of surrounding medium [22]. Among $\mathrm{Cu}, \mathrm{Ag}$, and $\mathrm{Au} ; \mathrm{Ag}$ possesses the highest plasmon excitation efficiency [23, 24]. Besides this, Ag NPs are cheaper than Au NPs. Thus, they have received more popularity than Au NPs. A single Ag nanoparticle interacts with light more effectively than that of any inorganic or organic chromophore of the same dimension [22, 25]. In recent years, a lot of colorimetric sensors based on Au and Ag NPs have been developed for the determination of biomolecules [26, 27], metal ions [28-30], drugs [20, 31-34], pesticides [35, 36], and phosgene gas [37].

In the present work, a new colorimetric sensing method has been developed to detect fluoxetine. It is based on color change of Ag NPs solution. The proposed technique is time saving, easy, and free of sophisticated instrumentation. To the best of our knowledge the use of nanoparticles as a colorimetric probe has not been reported for the detection of fluoxetine.

\section{Experimental}

\subsection{Chemicals}

All the chemicals used in experimental work were of analytical grade. Silver nitrate $\left(\mathrm{AgNO}_{3}\right)$, sodium borohydride $\left(\mathrm{NaBH}_{4}\right)$, and trisodium citrate $\left(\mathrm{C}_{6} \mathrm{H}_{9} \mathrm{Na}_{3} \mathrm{O}_{9}\right)$ were obtained from Merck (Darmstadt, Germany). Buffer solutions were prepared by using potassium chloride $(\mathrm{KCl})$ Fluka (Switzerland), hydrochloric acid (37\%), acetic acid $\left(\mathrm{C}_{2} \mathrm{H}_{4} \mathrm{O}_{2}\right)$, sodium hydroxide $(\mathrm{NaOH})$, sodium tetraborate decahydrate $\left(\mathrm{H}_{20} \mathrm{Na}_{2} \mathrm{~B}_{4} \mathrm{O}_{17}\right)$, sodium acetate $\left(\mathrm{C}_{2} \mathrm{H}_{3} \mathrm{NaO}_{2}\right)$, boric acid $\left(\mathrm{H}_{3} \mathrm{BO}_{3}\right)$ obtained from Merck (Darmstadt, Germany) and Sigma Aldrich (Switzerland). Fluoxetine hydrochloride standard was kindly provided by Wilshire laboratories (Pvt.) Ltd Karachi, Pakistan. Methanol was purchased from Sigma Aldrich (Germany). The pharmaceutical tablets and capsules containing fluoxetine were bought from the local market.

SN Applied Sciences

\subsection{Instrumentation}

UV-Vis absorption spectra of CIT-Ag NPs were recorded on Hitachi 220 double beam spectrophotometer (Hitachi Pvt. Ltd, Tokyo, Japan) employing $1 \mathrm{~cm}$ dual quartz cuvettes. Orion $420 \mathrm{~A} \mathrm{pH}$ meter equipped with glass electrodes and internal reference electrode (Orion Research In, Boston, USA) was used to confirm $\mathrm{pH}$ of buffer solutions. FT-IR spectra were recorded using Nicolet Atavar 330 (Thermo Nicolet corporation, USA) with attenuated total reflectance accessary (smart partner) within range of $4000-600 \mathrm{~cm}^{-1}$. An Allegra $64 \mathrm{R}$ centrifuge machine (Beckman Coulter, USA) was used to centrifuge sample solutions. The structural and morphological details of CIT-Ag NPs were analyzed on scanning electron microscope (JEOL JSM-6490 LV), at the Centre for Pure and Applied Geology, University of Sindh, Jamshoro. Zeta potential and size distribution of CIT-Ag NPs before and after interaction with fluoxetine were analyzed at Department of Metallurgy and Materials Engineering, Mehran University of Engineering and Technology, Jamshoro by employing Malvern ZS-Nano analyzer (Malvern instrument Inc., London, U.K).

\subsection{Synthesis of Ag NPs}

Citrate-capped Ag NPs were synthesized according to reported method [38, 39], which involved chemical reduction of $\mathrm{AgNO}_{3}$ salt by $\mathrm{NaBH}_{4}$ in presence of sodium citrate as a capping agent. Briefly, $78.0 \mathrm{ml}$ of $0.64 \mathrm{mM} \mathrm{AgNO}_{3}$ was taken in $100 \mathrm{ml}$ volumetric flask followed by addition of $2.0 \mathrm{ml}$ of $50 \mathrm{mM}$ tri sodium citrate under vigorous stirring. 20 min later, $20.0 \mathrm{ml}$ of $25.11 \mathrm{mM} \mathrm{NaBH}_{4}$ was added into volumetric flask at room temperature and the solution was further stirred for $1 \mathrm{~h}$. As a result, dark colloidal solution was turned to bright yellow indicating the synthesis of CIT-Ag NPs. The solution was then stored at $4.0 \pm 2.0^{\circ} \mathrm{C}$ in refrigerator in dark to keep the solution stable for several weeks.

\subsection{Stock solution preparation}

The stock solution of standard fluoxetine $\mathrm{HCl}(1 \mathrm{mg} / \mathrm{ml})$ was prepared by dissolving $25 \mathrm{mg}$ of standard fluoxetine in $25 \mathrm{ml}$ methanol. The working solution $(100 \mu \mathrm{g} / \mathrm{ml})$ was then prepared by appropriate dilution of stock solution with methanol.

\subsection{General procedure for detection of fluoxetine}

$2 \mathrm{ml}$ of CIT-Ag NPs was transferred to $10 \mathrm{ml}$ volumetric flask, followed by addition of $1 \mathrm{ml}$ buffer $(\mathrm{pH} 8), 1 \mathrm{ml}$ of 
$1 \mathrm{mg} / \mathrm{ml}$ of standard fluoxetine and the volume was adjusted with distilled water. A change in color was noted and absorbance of sample solution was recorded within the wavelength range of $300-700 \mathrm{~nm}$ against distilled water.

\subsection{Preparation of samples for characterization}

The sample preparation for characterization by FT-IR and SEM involved centrifugation of sufficient quantity of CITAg NPs in absence and presence of fluoxetine at $\mathrm{pH} 8$ at $5000 \mathrm{rpm}$ at room temperature for about half an hour. The sample solution containing fluoxetine had the concentration of $100 \mu \mathrm{g} / \mathrm{ml}$. The supernatant layer was discarded and precipitates (ppts) were collected. They were then washed with distilled water and dried in air. The ppts in dried powder form were then analyzed by FT-IR and SEM techniques.

The DLS for size distribution and zeta potential of CIT$\mathrm{Ag}$ NPs without fluoxetine and with fluoxetine were also determined. In this regard, $2 \mathrm{ml}$ of sample was taken from sample solution prepared following general procedure for detection of fluoxetine. The sample was then diluted up to $20 \mathrm{ml}$ with distilled water to get a final concentration of fluoxetine $10 \mu \mathrm{g} / \mathrm{ml}$. The concentration of fluoxetine in original solution was $100 \mu \mathrm{g} / \mathrm{ml}$. Same procedure was followed to prepare sample without fluoxetine.

\subsection{Selectivity}

$4 \mathrm{ml} \mathrm{CIT-Ag} \mathrm{NPs} \mathrm{was} \mathrm{transferred} \mathrm{into} \mathrm{a} \mathrm{series} \mathrm{of} 10 \mathrm{ml}$ volumetric flasks. Then, $1 \mathrm{ml}$ buffer of $\mathrm{pH} 8,0.6 \mathrm{ml}$ of $100 \mu \mathrm{g} /$ $\mathrm{ml}$ fluoxetine and $0.6 \mathrm{ml}$ of $1 \mathrm{mg} / \mathrm{ml}$ of various interfering species (glucose, sucrose, starch, $\mathrm{Na}^{+}$, and $\mathrm{Ca}^{+2}$ ) were added separately. The final volume was adjusted to $10 \mathrm{ml}$ with distilled water. In case of $\mathrm{Na}^{+}$and $\mathrm{Ca}^{+2}$, the selectivity was also examined using $1.2 \mathrm{ml}$ of $1 \mathrm{mg} / \mathrm{ml}$ of $\mathrm{Na}^{+}$and $\mathrm{Ca}^{+2}$ separately. The contents were mixed well and the absorbances were recorded at $500 \mathrm{~nm}$ against distilled water.

\subsection{Analysis of pharmaceutical preparations}

Five tablets of futine and five capsules of flux each containing $20 \mathrm{mg}$ fluoxetine $\mathrm{HCl}$ were weighed separately and ground to fine powder. Mass of powder equivalent to $25 \mathrm{mg}$ was then dissolved in $25 \mathrm{ml}$ methanol. The solution was then shaken and filtered to get clear solution. The remaining volume was adjusted with methanol to obtain approximately $1 \mathrm{mg} / \mathrm{ml}$ stock solution. The working solution of $100 \mu \mathrm{g} / \mathrm{ml}$ was prepared from stock solution by dilution with methanol. Different concentrations of fluoxetine were taken within calibration range $(2-10 \mu \mathrm{g} / \mathrm{ml})$ and the solutions were analyzed by following the general

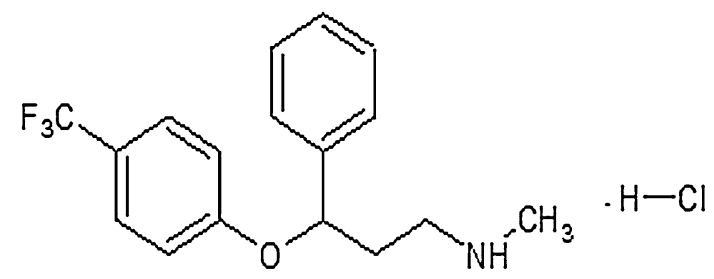

Fig. 1 Chemical structure of fluoxetine $\mathrm{HCl}$

procedure for detection of fluoxetine. Quantitation was then made from linear regression equation.

\subsection{Procedure for analysis of fluoxetine in biological fluids}

$5 \mathrm{ml}$ of blood sample was collected from healthy volunteer at Institute of Advanced Research Studies in Chemical Sciences, University of Sindh, Jamshoro, who has not taken any medicine at least one preceding week. The blood sample was centrifuged at $4000 \mathrm{rpm}$ at room temperature for about $20 \mathrm{~min}$ to separate red blood cells. After separating supernatant layer, methanol was added in double quantity and sample was again centrifuged at $4000 \mathrm{rpm}$. $1 \mathrm{ml}$ of supernatant was transferred to $10 \mathrm{ml}$ volumetric flask, then added $4 \mathrm{ml} \mathrm{CIT-Ag} \mathrm{NPs} \mathrm{at} \mathrm{pH} 8$ and $4 \mu \mathrm{g} / \mathrm{ml}$ fluoxetine standard at final concentration. The volume was adjusted to $10 \mathrm{ml}$ with distilled water. Quantitation was made for average responses $(n=3)$ of spiked blood serum samples from linear regression equation. The $\%$ recoveries were also calculated for three replicate measurements of sample.

Urine sample $(5 \mathrm{ml})$ of healthy volunteer was mixed with twice quantity of methanol and centrifuged at $4000 \mathrm{rpm}$ for $20 \mathrm{~min}$. Supernatant layer was separated and $1 \mathrm{ml}$ of supernatant was treated as for blood sample. The quantitation was made from linear regression equation.

Urine sample was also examined without prior deproteinization. In this regard, $3 \mathrm{ml}$ of urine of healthy volunteer was added with $1 \mathrm{ml}$ of $1 \mathrm{mg} / \mathrm{ml}$ fluoxetine. The volume was adjusted to $10 \mathrm{ml}$ with methanol. The contents were centrifuged at $4000 \mathrm{rpm}$ at room temperature for $20 \mathrm{~min}$. The supernatant was collected and $0.6 \mathrm{ml}$ of the solution was processed as Sect. 2.5. The quantitation was made from linear regression equation.

\section{Results and discussion}

\subsection{Colorimetric sensing mechanism}

The chemical structure of fluoxetine shows that it contains one secondary amino group, three fluorine atoms, 
and one oxygen atom in its structure (Fig. 1). The amino group is basic in nature, thus exhibiting positive charge. CIT-Ag NPs possess negatively charged surface and remain in dispersed state due to electrostatic repulsion among nanoparticles $[25,39]$. The colorimetric sensing of fluoxetine is based on an electrostatic interaction between positively charged amino group of fluoxetine at $\mathrm{pH} 8$ and negatively charged CIT-Ag NPs (Fig. 2). Besides this, hydrogen bond may also form between nitrogen, fluorine, or oxygen from fluoxetine and hydrogen on the surface of CIT-Ag NPs leading to strong intermolecular forces among nanoparticles. As a result, the silver nanoparticles come close to one another and aggregate causing color change from yellow to dark brown.

\subsection{Characterization of CIT-Ag NPs before and after interaction with fluoxetine}

The bright yellow colored colloidal solution of CIT-Ag NPs formed was then analyzed by UV-Vis spectrophotometer. Spectral analysis of Ag NPs (Fig. 3) shows that in absence of fluoxetine a characteristic sharp peak is found at $400 \mathrm{~nm}$ corresponding to spherical shaped Ag NPs which confirms that they are in dispersed state $[38,40]$. The addition of fluoxetine to CIT-Ag NPs induced the aggregation of Ag NPs leading

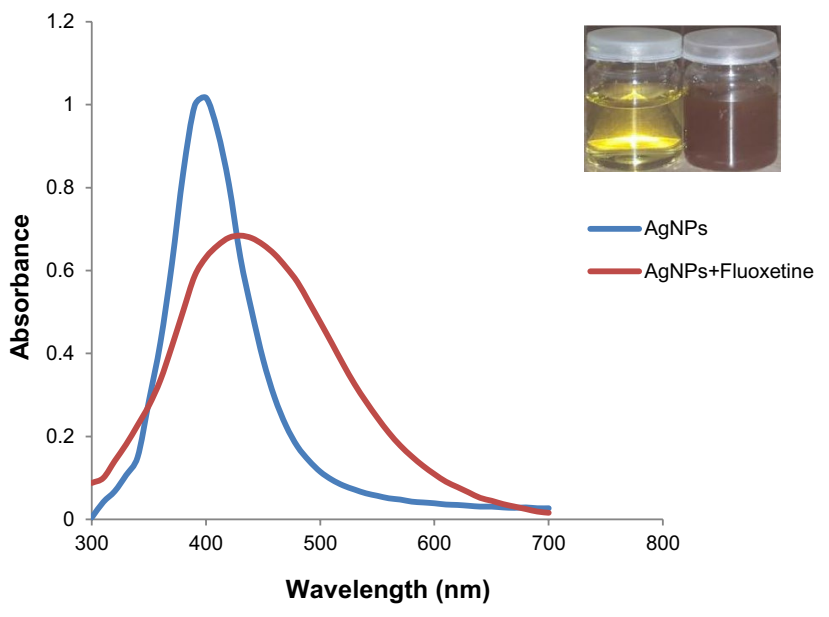

Fig. 3 UV-Vis absorption spectra and photographic image of CITAg NPs without and with fluoxetine $(100 \mu \mathrm{g} / \mathrm{ml})$

to color change from yellow to dark brown and as a result the absorbance at $400 \mathrm{~nm}$ was decreased and surface plasmon resonance band became broad and shifted towards longer wavelength. The FT-IR spectrum of CIT-Ag NPs without fluoxetine is shown in Fig. 4a which indicates peaks corresponding to $\mathrm{OH}$ stretching at $3202 \mathrm{~cm}^{-1},-\mathrm{C}=\mathrm{O}$ stretching

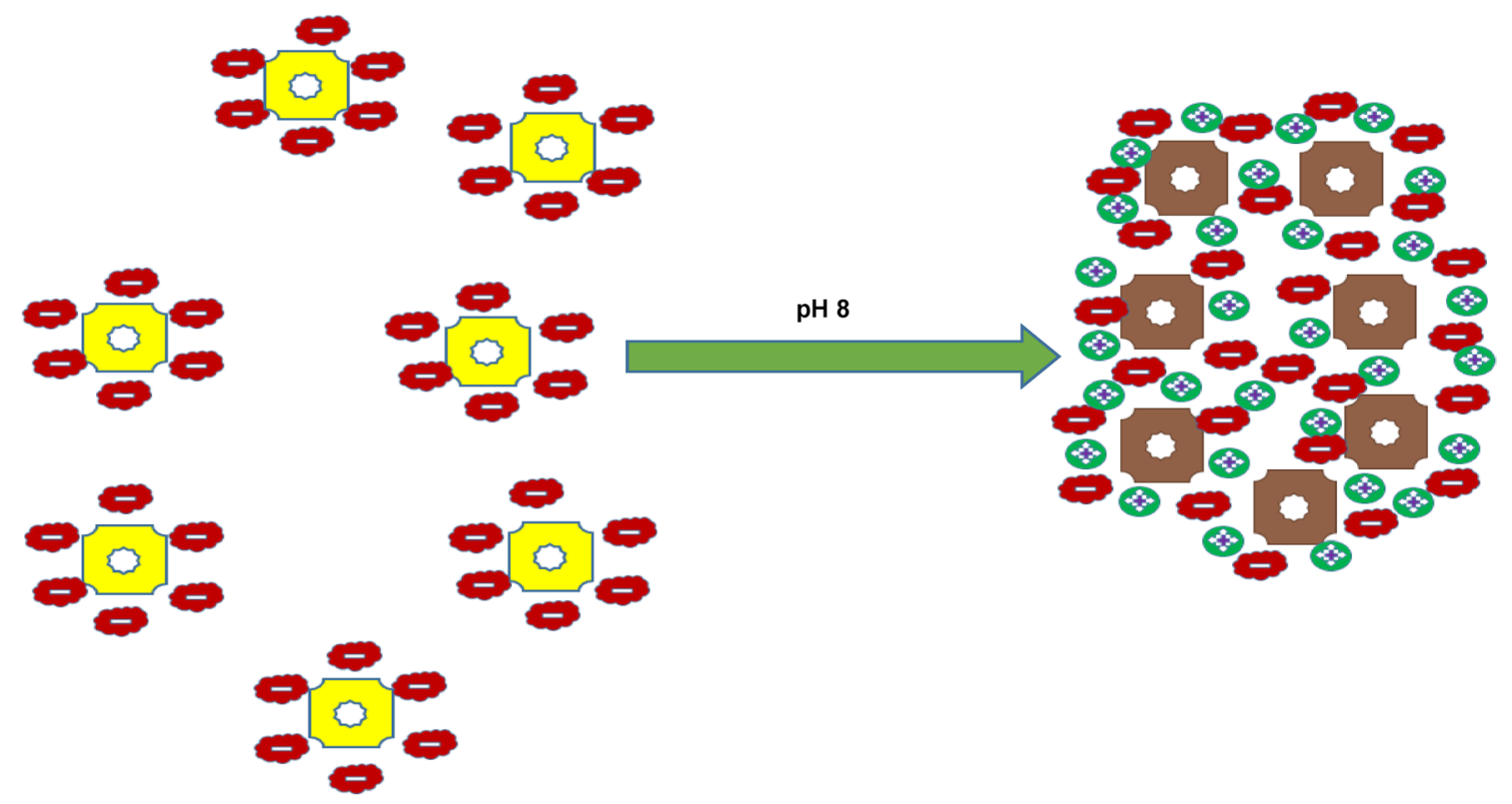

Dispersed state

Aggregated state

Ag NPs

Sodium citrate dihydrate

Fluoxetine

Fig. 2 Schematic representation of fluoxetine induced aggregation of CIT-Ag NPs 
(a)
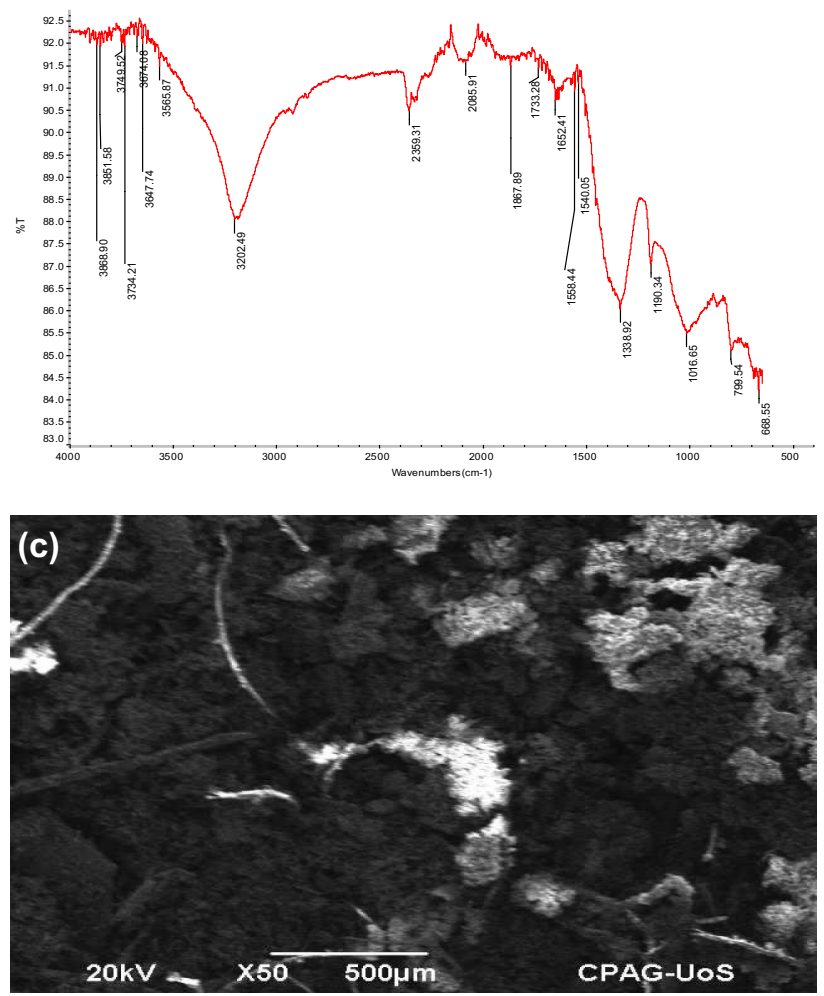

(b)
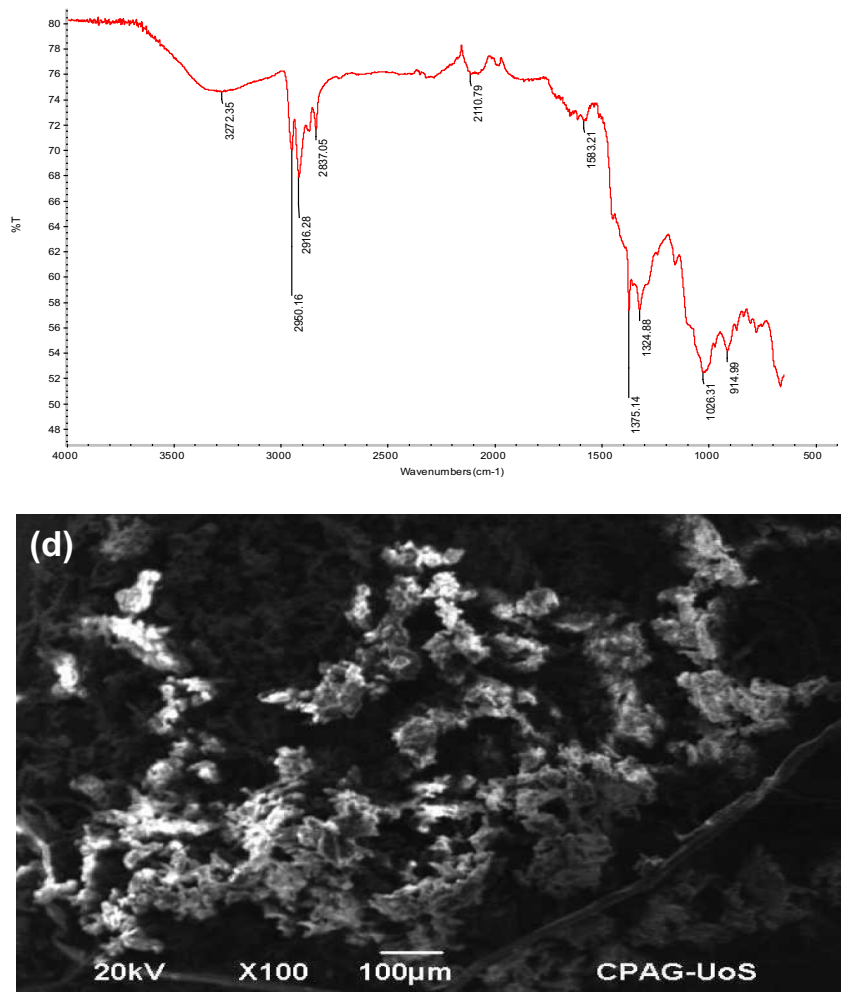

Fig. 4 a FT-IR spectra of CIT-Ag NPs without fluoxetine and b with $100 \mu \mathrm{g} / \mathrm{ml}$ fluoxetine. c SEM image of CIT-Ag NPs without fluoxetine and d with fluoxetine $(100 \mu \mathrm{g} / \mathrm{ml})$

at $1733-1652 \mathrm{~cm}^{-1}$. Moreover, the peaks at $1338 \mathrm{~cm}^{-1}$ and $1190 \mathrm{~cm}^{-1}$ represent $\mathrm{CH}_{2}$ and $\mathrm{C}-\mathrm{O}$ groups, respectively. Thus, FT-IR suggests the attachment of sodium citrate on the surface of Ag NPs. However, it can be seen that the intensity of stretching vibration of $\mathrm{OH}$ is reduced in FT-IR spectrum of CIT-Ag NPs in presence of fluoxetine. Furthermore, it can also be noticed from the FT-IR spectrum of CIT-Ag NPsfluoxetine (Fig. 4b) that certain additional peaks appear confirming the attachment of fluoxetine on the surface of citrate stabilized $\mathrm{Ag} N \mathrm{NPs}$ thereby inducing aggregation. The peaks at $2950-2837 \mathrm{~cm}^{-1}$ confirm $\mathrm{CH}$ stretching of $\mathrm{CH}_{3}{ }^{\prime} \mathrm{CH}_{2}$ groups while peak at $1375 \mathrm{~cm}^{-1}$ corresponds to $\mathrm{CH}_{3}$ group bending vibration. The stretching vibration of $\mathrm{C}-\mathrm{F}$ group in CIT-Ag NPs-fluoxetine occurs at $1324 \mathrm{~cm}^{-1}$. The peak at $1026 \mathrm{~cm}^{-1}$ represents the stretching vibration of C-N group. Figure 4c shows that CIT-Ag NPs are of somewhat spherical shape corresponding to dispersed state. However, in presence of fluoxetine, the morphology of CIT-Ag NPs is quite different and it seems to be flower-like which confirms the aggregation of Ag NPs (Fig. 4d). Another technique which was employed to characterize Ag NPs is dynamic light scattering technique. It involves laser beam to illuminate suspension of particles. From Fig. $5 \mathrm{a}$, it is obvious that the size of Ag NPs is $4 \mathrm{~nm}$ in diameter in absence of fluoxetine and the peak is monomodal in nature which further confirms the shape to be spherical [41]. Conversely, three peaks are seen in Fig. 5b. It may be due to flower-like nanoparticles. Moreover, it can also be noticed from figure that average mean diameter is greatly increased from $4 \mathrm{~nm}$ to $176 \mathrm{~nm}$ due to interaction of fluoxetine with CIT-Ag NPs. The zeta potential value was $-36.2 \mathrm{mV}$ for colloidal solution of CITAg NPs (Fig. 5c), indicating the negative charge at surface of Ag NPs. The higher magnitude of zeta potential value reflects stability of colloidal dispersion due to electrostatic repulsion of negatively charged Ag NPs which is consistent with reported procedures $[42,43]$. From Fig. $5 d$, it is clear that zeta potential value is decreased to $-15.4 \mathrm{mV}$ due to interaction of positively charged fluoxetine with negatively charged CIT-Ag NPs. It results in an increase in electrostatic forces among nanoparticles leading to aggregation thereby decreasing the stability of Ag NPs.

\subsection{Factors influencing colorimetric sensing}

\subsubsection{Effect of $\mathrm{pH}$}

The effect of $\mathrm{pH}$ on absorbance of CIT-Ag NPs in presence of fluoxetine was investigated from $\mathrm{pH} 2-10$ by monitoring 
(a)

Size Distribution by Volume

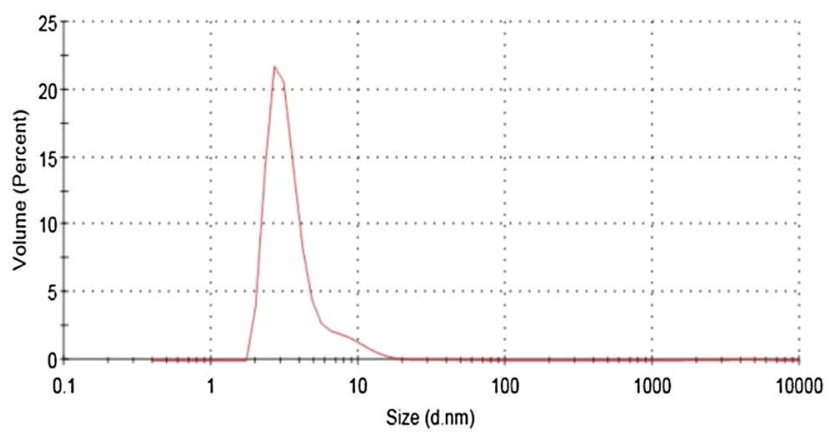

(c)

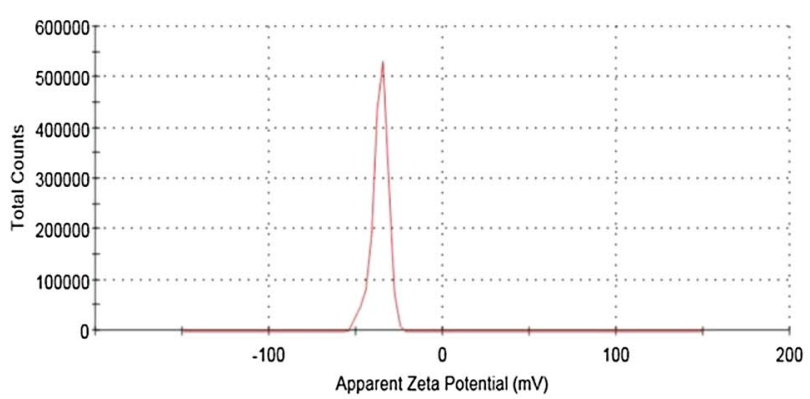

(b)

Size Distribution by Volume

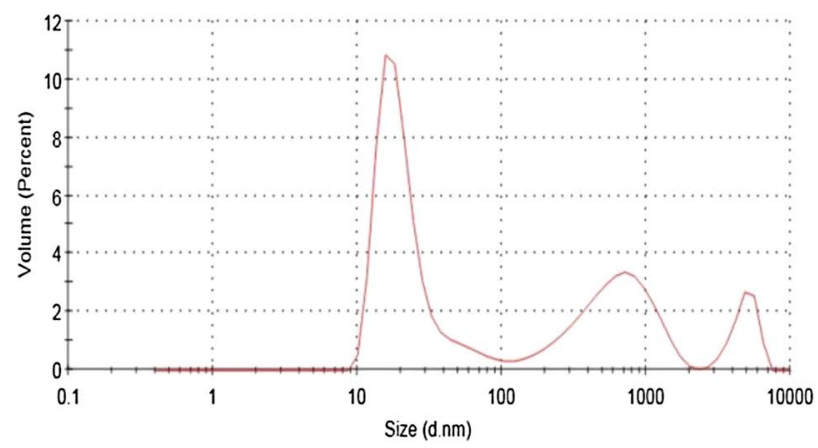

(d)

Zeta Potential Distribution

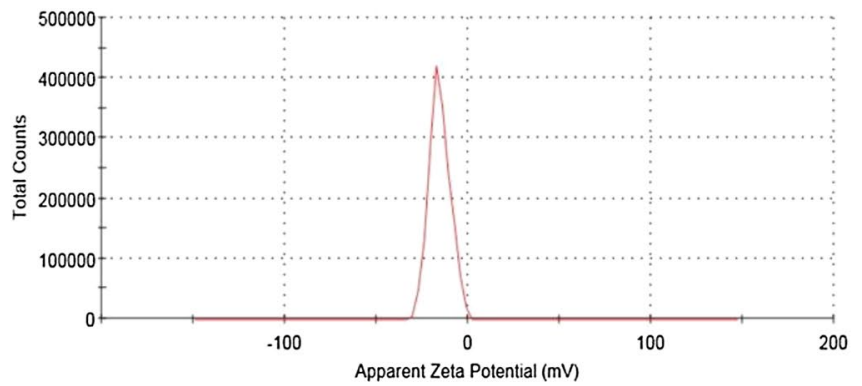

Fig. 5 a Size distribution of CIT-Ag NPs without fluoxetine and b with $10 \mu \mathrm{g} / \mathrm{ml}$ fluoxetine. c Zeta potential of CIT-Ag NPs without fluoxetine and $\mathbf{d}$ with fluoxetine $(10 \mu \mathrm{g} / \mathrm{ml})$

the UV-Vis spectra within the wavelength range of $300-700 \mathrm{~nm}$. As, it is clear from Fig. 6a that the maximum absorbance occurred at $\mathrm{pH} 8$, thus we selected $\mathrm{pH} 8$ for the whole experimental study of fluoxetine. Moreover, it was also observed during study of $\mathrm{pH}$ effect that at lower $\mathrm{pH}$ $(<4)$, the CIT-Ag NPs solution was unstable and the aggregation occurred without adding any analyte resulting in color change of Ag NPs solution from yellow to colorless which is in accordance with reported literature [44]. This was due to neutralization of surface charge of Ag NPs. However, at higher pH values i.e. $>7$ and $<11$, the CIT-Ag NPs were stable, the characteristic color of Ag NPs solution remained bright yellow even after addition of buffer solution. The addition of fluoxetine to CIT-Ag NPs at pH 8 lead to color change from yellow to dark brown due to aggregation induced by fluoxetine.

\subsubsection{Effect of time}

The influence of time on absorbance of CIT-Ag NPs was studied for $1 \mathrm{~h}$ in presence of $10 \mu \mathrm{g} / \mathrm{ml}$ fluoxetine at $\mathrm{pH}$ 8 as shown in Fig. $6 \mathrm{~b}$. The absorbance of the sample solution was recorded within $5 \mathrm{~min}$ at $500 \mathrm{~nm}$ then at an interval of $15 \mathrm{~min}$. It was found that absorbance was slightly decreased after 5 min and then remained constant from $20 \mathrm{~min}$ to $60 \mathrm{~min}$. Thus, $20 \mathrm{~min}$ was chosen as an optimum time for study of fluoxetine.

\subsubsection{Effect of concentration of fluoxetine}

To investigate the influence of concentration of fluoxetine on absorbance, the calibration curve was plotted within concentration range of $2-10 \mu \mathrm{g} / \mathrm{ml}$. Figure $6 c$ shows that the absorption ratio at $A_{500} / A_{400}$ is increased linearly with increase in fluoxetine concentration with $\mathrm{R}^{2}$ of 0.9998 . Moreover, it was also observed that color of CIT-Ag NPs solution changed from yellow to brownish yellow and then to brown upon increasing fluoxetine concentration. This enables one to determine fluoxetine by naked eye. The limit of detection (LOD) and limit of quantitation (LOQ) were calculated from standard deviation of $y$ intercept using linear regression equation and found to be 0.18 and $0.54 \mu \mathrm{g} / \mathrm{ml}$, respectively, showing proposed method to be highly sensitive. 

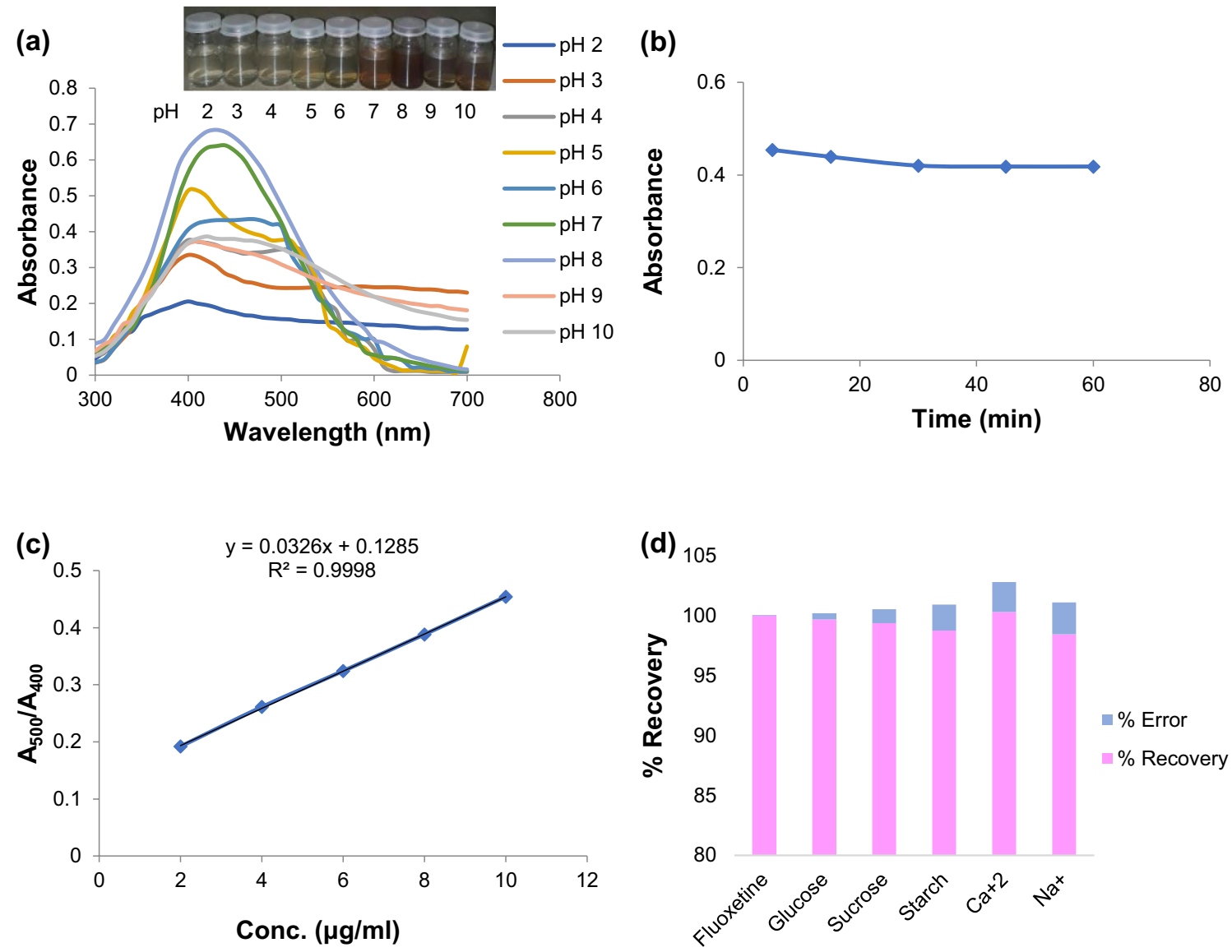

Fig. 6 a UV-Vis absorption spectra and photographic image of CITAg NPs with fluoxetine $(100 \mu \mathrm{g} / \mathrm{ml})$ at various $\mathrm{pH}$. b Effect of time on absorbance of CIT-Ag NPs with $10 \mu \mathrm{g} / \mathrm{ml}$ fluoxetine. c Effect of

\subsection{Intra-day and inter-day variation}

Intra-day and inter-day precision were evaluated at a concentration of fluoxetine $6 \mu \mathrm{g} / \mathrm{ml}$ under optimum conditions. The relative standard deviation (RSD) was found to be $<2 \%(n=5)$ for both intra-day and inter-day precision assays. This shows that our developed method is highly repeatable and reproducible.

\subsection{Selectivity of method}

The selectivity of the proposed colorimetric assay was examined by adding various pharmaceutical additives including glucose, sucrose, starch, $\mathrm{Ca}^{+2}$, and $\mathrm{Na}^{+}$to CITAg NPs solution individually in a concentration 10 times more than the concentration of fluoxetine under optimum conditions. The concentration of fluoxetine was $6 \mu \mathrm{g} / \mathrm{ml}$. A relative error of below $3 \%$ was obtained (Fig. $6 \mathrm{~d}$ ). It was found that absorbance remained almost similar even in

concentration of fluoxetine $(2-10 \mu \mathrm{g} / \mathrm{ml})$. d Interference effect of pharmaceutical additives (fluoxetine $6 \mu \mathrm{g} / \mathrm{ml}$, additives $60 \mu \mathrm{g} / \mathrm{ml}$ )

presence of foreign species. In case of $\mathrm{Na}^{+}$and $\mathrm{Ca}^{+2}$, the selectivity was also investigated at a concentration of $120 \mu \mathrm{g} / \mathrm{ml}$. The results indicate that $\mathrm{Na}^{+}$did not interfere at higher concentration and the relative error was $1.32 \%$. However, $\mathrm{Ca}^{+2}$ indicated relative error above $10 \%$. It shows that $\mathrm{Ca}^{+2}$ is interfering at higher concentration.

\subsection{Analysis of fluoxetine in pharmaceutical formulation and biological fluids}

Fluoxetine was determined in commercially available futine tablet and flux capsule each containing $20 \mathrm{mg}$ fluoxetine $\mathrm{HCl}$. The RSD calculated was $<2 \%(n=3)$ with the recoveries ranged from 98 to $99.5 \%$. The amount found agreed well with the labelled amount on packet (Table 1). Furthermore, the cited antidepressant was also analyzed by standard addition method. The results are summarized in Table 2. 
Table 1 Pharmaceutical analysis of fluoxetine using CIT-Ag NPs

\begin{tabular}{llllll}
\hline S.no. & $\begin{array}{l}\text { Name of } \\
\text { tablet/ } \\
\text { capsule }\end{array}$ & $\begin{array}{l}\text { Labelled } \\
\text { amount } \\
(\mathrm{mg})\end{array}$ & $\begin{array}{l}\text { Amount } \\
\text { found } \\
(\mathrm{mg})\end{array}$ & $\begin{array}{l}\% \text { RSD } \\
(\mathrm{n}=3)\end{array}$ & \% Recovery \\
\hline 1. & $\begin{array}{c}\text { Futine } \\
\text { tablet }\end{array}$ & 20 & 19.9 & 1.64 & 99.5 \\
2. & $\begin{array}{c}\text { Flux cap- } \\
\text { sule }\end{array}$ & 20 & 19.66 & 1.93 & 98.3 \\
\hline
\end{tabular}

Similarly, the developed colorimetric assay was applied to analyze fluoxetine in biological fluids including spiked human urine and blood serum samples. RSDs for spiked human urine and blood serum samples were 1.30 and $1.67 \%(n=3)$, respectively, with recoveries of $97.75-98.5 \%$. Additionally, the urine sample was also analyzed without prior deproteinization. The spiked sample indicated relative error of $2.65 \%$ with recovery of $102.6 \%$. This supports that spiked human urine and blood serum samples did not interfere the determination of fluoxetine.

The results were compared with other reported procedures in terms of sensitivity and ease of analysis. Table 3 shows that the sensitivity of developed assay is better than spectrophotometric methods and capillary zone electrophoresis. However, microextraction combined with ultra-high-performance liquid chromatography (UHPLC) is highly sensitive than our proposed method but it requires complex equipment.

\section{Conclusions}

A new colorimetric sensing approach was developed for the analysis of fluoxetine in pure form, pharmaceutical preparation, spiked human urine and blood serum samples using CIT-Ag NPs. The experimental parameters were studied and the best $\mathrm{pH}$ for colorimetric sensing of fluoxetine was found to be 8 . The proposed technique is simple, reliable, sensitive and selective. LOD and LOQ were found to be 0.18 and $0.54 \mu \mathrm{g} / \mathrm{ml}$, respectively. The colorimetric platform made it possible to detect fluoxetine visually on the basis of color change of Ag NPs from yellow to dark brown within few minutes without requiring any special additives and expensive instrumentation. This simple and speedy analytical approach would hold great potential for detection of fluoxetine in clinical analysis.

Table 2 Analysis of fluoxetine using CIT-Ag NPs by standard

\begin{tabular}{llllll}
\hline S.no. & $\begin{array}{l}\text { Amount of futine } \\
\text { taken }(\mu \mathrm{g} / \mathrm{ml})\end{array}$ & $\begin{array}{l}\text { Amount of standard } \\
\text { added }(\mu \mathrm{g} / \mathrm{ml})\end{array}$ & $\begin{array}{l}\text { Total amount of } \\
\text { drug found }(\mu \mathrm{g} / \mathrm{ml})\end{array}$ & $\%$ RSD $(\mathrm{n}=3)$ & \% Recovery \\
\hline 1. & 4.0 & 0.0 & 3.94 & 1.19 & 98.5 \\
2. & 4.0 & 2.0 & 5.97 & 2.30 & 99.5 \\
3. & 4.0 & 4.0 & 7.93 & 1.43 & 99.12 \\
4. & 4.0 & 6.0 & 9.89 & 1.37 & 98.9 \\
\hline
\end{tabular}
addition method

Table 3 Comparison of present colorimetric assay with reported methods

\begin{tabular}{lclll}
\hline Analytical technique & $\begin{array}{l}\text { Calibration } \\
\text { range }(\mu \mathrm{g} / \mathrm{ml})\end{array}$ & LOD $(\mu \mathrm{g} / \mathrm{ml})$ & Sample analysed & References \\
\hline UV-Vis spectroscopy & $2-24$ & 0.53 & Bulk form & {$[14]$} \\
Microextraction combined with UHPLC & $0.1-5.0$ & 0.080 & Urine sample & {$[45]$} \\
Spectrophotometric & $0.15-2.5$ & 0.06 & Urine sample & {$[46]$} \\
${ }^{19}$ F NMR spectroscopic method & $100-1350$ & $5.9-7.5$ & Pharmaceutical formulations & {$[47]$} \\
Bromatometric method & $0.4-12$ & 0.32 & Pharmaceuticals and plasma & {$[48]$} \\
Capillary zone electrophoresis & $2.5-50$ & $1.69-1.77$ & Pharmaceutical formulation & {$[49]$} \\
CIT-Ag NPs based colorimetric assay & $2-10$ & 0.18 & Pure form, pharmaceutical formulation, Present method \\
& & & Spiked human urine, and blood serum &
\end{tabular}


Acknowledgements We are grateful to Institute of Advanced Research Studies in Chemical Sciences, University of Sindh, Jamshoro, Pakistan for supporting the research project. We are also thankful to Wilshire laboratories (Pvt) Ltd. Karachi for providing standard of fluoxetine $\mathrm{HCl}$.

\section{Compliance with ethical standards}

Conflict of interest The authors declare that they have no conflict of interest.

Ethical approval The blood and urine samples of healthy volunteers were obtained with verbal permission and they were informed about the objectives of the research project.

\section{References}

1. Bell CC (1994) DSM-IV: diagnostic and statistical manual of mental disorders. JAMA 272:828-829

2. Cheer SM, Goa KL (2001) Fluoxetine. Drugs $61: 81-110$

3. Benfield P, Heel RC, Lewis SP (1986) Fluoxetine. Drugs 32:481-508

4. Eap CB, Baumann P (1996) Analytical methods for the quantitative determination of selective serotonin reuptake inhibitors for therapeutic drug monitoring purposes in patients. $J$ Chromatogr B Biomed Sci Appl 686:51-63

5. Wong DT, Bymaster FP, Engleman EA (1995) Prozac (fluoxetine, Lilly 110140), the first selective serotonin uptake inhibitor and an antidepressant drug: twenty years since its first publication. Life Sci 57:411-441

6. Desiderio C, Rudaz S, Raggi MA, Fanall S (1999) Enantiomeric separation of fluoxetine and norfluoxetine in plasma and serum samples with high detection sensitivity capillary electrophoresis. Electrophoresis 20:3432-3438

7. Pucci V, Fanali S, Sabbioni C, Raggi MA (2002) Separation of five recently commercialized selective serotonin reuptake inhibitor antidepressants by capillary electrophoresis. J Sep Sci 25:1096-1100

8. Raggi MA, Mandrioli R, Casamenti G, Volterra V, Desiderio C, Fanali S (1999) Improved HPLC determination of fluoxetine and norfluoxetine in human plasma. Chromatographia 50:423-427

9. Juan $\mathrm{H}$, Zhiling $\mathrm{Z}$, Huande $\mathrm{L}$ (2005) Simultaneous determination of fluoxetine, citalopram, paroxetine, venlafaxine in plasma by high performance liquid chromatography-electrospray ionization mass spectrometry (HPLC-MS/ESI). J Chromatogr B Anal Technol Biomed Life Sci 820:33-39. https://doi.org/10.1016/j. jchromb.2005.03.006

10. Vlase L, Imre S, Leucuta S (2005) Determination of fluoxetine and its $\mathrm{N}$-desmethyl metabolite in human plasma by high-performance liquid chromatography. Talanta 66:659-663

11. Tournel G, Houdret N, Hedouin V, Deveaux M, Gosset D, Lhermitte M (2001) High-performance liquid chromatographic method to screen and quantitate seven selective serotonin reuptake inhibitors in human serum. J Chromatogr B Biomed Sci Appl 761:147-158

12. Malfará WR, Bertucci $C$, Costa Queiroz ME, Dreossi Carvalho SA, de Lourdes Pires Bianchi M, Cesarino EJ, Crippa JA, Costa Queiroz RH (2007) Reliable HPLC method for therapeutic drug monitoring of frequently prescribed tricyclic and nontricyclic antidepressants. J Pharm Biomed Anal 44:955-962
13. Nouws HPA, Delerue-Matos C, Barros AA, Rodrigues JA, SantosSilva A, Borges F (2007) Square-wave adsorptive-stripping voltammetric detection in the quality control of fluoxetine. Anal Lett 40:1131-1146

14. Kumar A, Jain SK (2016) Development and validation of uv-spectroscopy based stability indicating method for the determination of fluoxetine hydrochloride. Anal Chem Lett 6:894-902. https://doi.org/10.1080/22297928.2016.1278180

15. Prabhakar AH, Patel VB, Giridhar R (1999) Spectrophotometric determination of fluoxetine hydrochloride in bulk and in pharmaceutical formulations. J Pharm Biomed Anal 20:427-432

16. Afkhami A, Madrakian T, Khalafi L (2006) Spectrophotometric determination of fluoxetine by batch and flow injection methods. Chem Pharm Bull 54:1642-1646

17. Truta L, Castro AL, Tarelho S, Costa P, Sales MGF, Teixeira HM (2016) Antidepressants detection and quantification in whole blood samples by GC-MS/MS, for forensic purposes. J Pharm Biomed Anal 128:496-503

18. Sahoo SK, Parveen S, Panda JJ (2007) The present and future of nanotechnology in human health care. Nanomedicine: nanotechnology. Biol Med 3:20-31. https://doi.org/10.1016/j. nano.2006.11.008

19. Wong KKY, Liu X (2010) Silver nanoparticles-the real "silver bullet" in clinical medicine? Medchemcomm 1:125-131

20. Guo L, Zhong J, Wu J, Fu F, Chen G, Zheng X, Lin S (2010) Visual detection of melamine in milk products by label-free gold nanoparticles. Talanta 82:1654-1658

21. Lopatynskyi AM, Lopatynska OG, Guo LJ, Chegel VI (2011) Localized surface plasmon resonance biosensor-part I: theoretical study of sensitivity-extended Mie approach. IEEE Sens J 11:361-369

22. Kelly KL, Coronado E, Zhao LL, Schatz GC (2002) The optical properties of metal nanoparticles: the influence of size, shape, and dielectric environment. J Phys Chem B 107:668-677. https ://doi.org/10.1021/jp026731y

23. Evanoff DD Jr, Chumanov G (2005) Synthesis and optical properties of silver nanoparticles and arrays. ChemPhysChem 6:1221-1231

24. Li H, Li F, Han C, Cui Z, Xie G, Zhang A (2010) Highly sensitive and selective tryptophan colorimetric sensor based on 4,4-bipyridine-functionalized silver nanoparticles. Sens Actuators B Chem 145:194-199

25. Evanoff DD, Chumanov G (2004) Size-controlled synthesis of nanoparticles. 2. Measurement of extinction, scattering, and absorption cross sections. J Phys Chem B 108:13957-13962

26. Palazzo G, Facchini L, Mallardi A (2012) Colorimetric detection of sugars based on gold nanoparticle formation. Sens Actuators B Chem 161:366-371

27. Ravindran A, Mani V, Chandrasekaran N, Mukherjee A (2011) Selective colorimetric sensing of cysteine in aqueous solutions using silver nanoparticles in the presence of $\mathrm{Cr}^{3+}$. Talanta 85:533-540

28. Gao Y-X, Xin J-W, Shen Z-Y, Pan W, Li X, Wu A-G (2013) A new rapid colorimetric detection method of $\mathrm{Mn}^{2+}$ based on tripolyphosphate modified silver nanoparticles. Sens Actuators B Chem 181:288-293

29. Hormozi-Nezhad MR, Abbasi-Moayed S (2014) A sensitive and selective colorimetric method for detection of copper ions based on anti-aggregation of unmodified gold nanoparticles. Talanta 129:227-232

30. Chen L, Li J, Chen L (2014) Colorimetric detection of mercury species based on functionalized gold nanoparticles. ACS Appl Mater Interfaces 6:15897-15904

31. Ling J, Sang Y, Huang CZ (2008) Visual colorimetric detection of berberine hydrochloride with silver nanoparticles. J Pharm Biomed Anal 47:860-864 
32. Li F, Feng Y, Zhao C, Tang B (2011) Simple colorimetric sensing of trace bleomycin using unmodified gold nanoparticles. Biosens Bioelectron 26:4628-4631

33. Qu JC, Chang YP, Ma YH, Zheng JM, Li HH, Ou QQ, Ren C, Chen XG (2012) A simple and sensitive colorimetric method for the determination of propafenone by silver nanoprobe. Sens Actuators B Chem 174:133-139

34. Kong S, Liao M, Gu Y, Li N, Wu P, Zhang T, He H (2016) Colorimetric recognition of pazufloxacin mesilate based on the aggregation of gold nanoparticles. Spectrochim Acta A Mol Biomol Spectrosc 157:244-250

35. Rohit JV, Solanki JN, Kailasa SK (2014) Surface modification of silver nanoparticles with dopamine dithiocarbamate for selective colorimetric sensing of mancozeb in environmental samples. Sens Actuators B Chem 200:219-226

36. Giannoulis KM, Giokas DL, Tsogas GZ, Vlessidis AG (2014) Ligand-free gold nanoparticles as colorimetric probes for the non-destructive determination of total dithiocarbamate pesticides after solid phase extraction. Talanta 119:276-283

37. Feng D, Zhang Y, Shi W, Li X, Ma H (2010) A simple and sensitive method for visual detection of phosgene based on the aggregation of gold nanoparticles. Chem Commun 46:9203-9205

38. Jana NR, Gearheart L, Murphy CJ (2001) Wet chemical synthesis of silver nanorods and nanowires of controllable aspect ratio. Chem Commun 0:617-618

39. Henglein A, Giersig M (1999) Formation of colloidal silver nanoparticles: capping action of citrate. J Phys Chem B 103:9533-9539

40. Creighton JA, Eadon DG (1991) Ultraviolet-visible absorption spectra of the colloidal metallic elements. J Chem Soc Faraday Trans 87:3881-3891

41. Roy P, Das B, Mohanty A, Mohapatra S (2017) Green synthesis of silver nanoparticles using Azadirachta indica leaf extract and its antimicrobial study. Appl Nanosci 7:843-850

42. Greenwood R, Kendall K (1999) Selection of suitable dispersants for aqueous suspensions of zirconia and titania powders using acoustophoresis. J Eur Ceram Soc 19:479-488
43. Hanaor D, Michelazzi M, Leonelli C, Sorrell CC (2012) The effects of carboxylic acids on the aqueous dispersion and electrophoretic deposition of $\mathrm{ZrO}_{2}$. J Eur Ceram Soc 32:235-244

44. Basu S, Ghosh SK, Kundu S, Panigrahi S, Praharaj S, Pande S, Jana S, Pal T (2007) Biomolecule induced nanoparticle aggregation: effect of particle size on interparticle coupling. J Colloid Interface Sci 313:724-734

45. Alves V, Gonçalves J, Conceição C, Câmara HMT, Câmara JS (2015) An improved analytical strategy combining microextraction by packed sorbent combined with ultra high pressure liquid chromatography for the determination of fluoxetine, clomipramine and their active metabolites in human urine. J Chromatogr A 1408:30-40

46. Bigdelifam D, Mirzaei $M$, Hashemi M, Amoli-Diva M, Rahmani O, Zohrabi P, Taherimaslak Z, Turkjokar M (2014) Sensitive spectrophotometric determination of fluoxetine from urine samples using charge transfer complex formation after solid phase extraction by magnetic multiwalled carbon nanotubes. Anal Methods 6:8633-8639. https://doi.org/10.1039/C4AY01266F

47. Shamsipur M, Dastjerdi LS, Haghgoo S, Armspach D, Matt $D$, Aboul-Enein HY (2007) Chiral selectors for enantioresolution and quantitation of the antidepressant drug fluoxetine in pharmaceutical formulations by ${ }^{19} \mathrm{~F}$ NMR spectroscopic method. Anal Chim Acta 601:130-138

48. Shah J, Jan MR, Khan MN, Durrani S (2012) Quantitative determination of fluoxetine in pharmaceuticals and plasma samples using bromatometric method. Am J Anal Chem 3:828

49. Ca^rcu-Dobrin M, Budău M, Hancu G, Gagyi L, Rusu A, Kelemen H (2017) Enantioselective analysis of fluoxetine in pharmaceutical formulations by capillary zone electrophoresis. Saudi Pharm J 25:397-403

Publisher's Note Springer Nature remains neutral with regard to jurisdictional claims in published maps and institutional affiliations. 